\title{
Comparative whole genome transcriptome analysis and fenugreek leaf extract modulation on cadmium-induced toxicity in liver cells
}

\author{
CAROLINE ODEWUMI ${ }^{1}$, LEKAN M. LATINWO ${ }^{1}$, ROY LEONARD LYLES II ${ }^{2}$, \\ VEERA L.D. BADISA ${ }^{1}$, COBB-ABDULLAH AHKINYALA ${ }^{3}$ and MARIJO KENT-FIRST ${ }^{1}$ \\ ${ }^{1}$ Department of Biological Sciences, Florida A\&M University, Tallahassee, FL $32307 ;{ }^{2}$ Memorial University Medical Center, \\ Savannah, GA 31404; ${ }^{3}$ Department of Natural Sciences, Virginia Union University, Richmond, VA 23222, USA
}

Received October 25, 2017; Accepted February 23, 2018

DOI: $10.3892 /$ ijmm.2018.3669

\begin{abstract}
Cadmium (Cd), an economically valuable metal, is widely used in various industrial processes. Although it is of economic value, it is hazardous to human health. Cd accumulates in vital organs where it causes various diseases. Natural compounds with chelating or antioxidant properties have been tested to reduce the toxic effect of $\mathrm{Cd}$. The anti-oxidant, anti-diabetic and hypocholesterolemic properties of fenugreek (Trigonella foenum-graecum) leaves make it a candidate for investigation as protective agent against $\mathrm{Cd}$-induced toxicity. In the present study, the protective effects of fenugreek leaf extract (FLE) on cell viability, morphology, and whole genomic transcription in cadmium chloride $\left(\mathrm{CdCl}_{2}\right)$-treated rat liver cells were analyzed. The cells were treated with $25 \mu \mathrm{M} \mathrm{CdCl}_{2}$ alone, or co-treated with $5 \mu \mathrm{g} / \mathrm{ml} \mathrm{FLE} \mathrm{for} 48 \mathrm{~h}$. The co-treated cells were pretreated with FLE for 2 or $4 \mathrm{~h}$, followed by $\mathrm{CdCl}_{2}$ treatment. Genomic transcription analysis was performed in the $\mathrm{CdCl}_{2}$-treated cells following treatment for $6 \mathrm{~h}$. The $\mathrm{CdCl}_{2}$ caused a significant decrease in viability $(35.8 \pm 4.1 \%)$ and morphological distortion of the cells, compared with the untreated control cells; whereas $4 \mathrm{~h}$ pretreatment with FLE $(5 \mu \mathrm{g} / \mathrm{ml})$ reversed the $\mathrm{Cd}$-induced morphology alteration and increased the cell viability to $102 \pm 3.8 \%$. Genomic transcription analysis of the $\mathrm{CdCl}_{2}$ only-treated cells showed 61 upregulated and 124 downregulated genes, compared with 180 upregulated and 162 downregulated genes in the FLE pretreated cells. Furthermore, 37 and $26 \%$ of the affected total genomic genes in the $\mathrm{CdCl}_{2}$ only-treated cells were involved in binding and catalytic activities, respectively, whereas 50 and $20 \%$ of the genes in the FLE pretreated cells were involved in binding and catalytic activities, respectively. In conclusion, these results suggested that genome transcriptome modula-
\end{abstract}

Correspondence to: $\mathrm{Dr}$ Caroline Odewumi, Department of Biological Sciences, Florida A\&M University, 1530 SMLK Boulevard, 501 Jones Hall, Tallahassee, FL 32307, USA

E-mail: caroline.odewumi@famu.edu

Key words: cadmium, rat liver cells, fenugreek leaf extract, protection, whole genome transcriptome analysis tion may be important in the protective effect of FLE against Cd-induced toxicity in normal rat liver cells.

\section{Introduction}

Cadmium (Cd) is a biologically non-essential heavy metal, however, it is one of the most toxic environmental and industrial pollutants due to its abuse in agricultural (fertilizers) and industrial products, including nickel-cadmium batteries, pigments, chemical stabilizers, metal coatings and alloys. Unfortunately, it is present almost ubiquitously in food (1-3), with the general population being exposed to $\mathrm{Cd}$ through drinking water and food (4). Approximately, two-thirds of $\mathrm{Cd}$ exposure through the diet is attributed to contaminated vegetables and one-third is attributed to animal products (5). In the United States, it is estimated that the average person consumes $\sim 30 \mu \mathrm{g}$ of $\mathrm{Cd}$ per day through food (6). It has also been classified as a type I carcinogen by the International Agency for Cancer Research (7).

$\mathrm{Cd}$ is a cumulative toxicant, which accumulates throughout life due to its long biological half-life (15-30 years) and poor excretion $(8,4)$. Acute and chronic Cd exposure leads to its accumulation predominantly in the liver and kidneys, in addition to other tissues and organs, causing several metabolic and histological disorders in humans and animals $(9,10)$. The molecular mechanisms of $\mathrm{Cd}$ toxicity are diverse and complex. It has been demonstrated that $\mathrm{Cd}$ causes damage to cells indirectly by the generation of reactive oxygen species, which leads to the unspecific oxidation of proteins and membrane lipids; and consequently causes DNA damage by depleting free radical scavengers, including glutathione, metallothioneins and protein-bound sulfhydryl groups $(11,12)$.

Various plants are important in traditional folk medicine and in pharmacological preparations for the treatment of various diseases. Trigonella foenum-graecum is an important spice used in various regions of the Asian, African and European continents. It is commonly called fenugreek. The seeds are commonly used as a spice in food preparations due to their potent flavor and aroma $(13,14)$. Fenugreek leaves are consumed widely in India as a green, leafy vegetable, and are a rich source of calcium, iron, $\beta$-carotene and vitamin $\mathrm{K}$ (15). The leaves and seeds are used to prepare extracts or powders for medicinal use (16). It has been shown that fenugreek 
extract can lower kidney/body weight ratio, blood glucose and blood lipid levels, and improve hemorheological properties in experimental diabetic rats following repeated treatment for 6 weeks (17). The medicinal efficacy of fenugreek has been shown experimentally in diabetic humans and rats (18-20). In type 1 diabetic animals, it has been shown that the supplementation of fenugreek in the diet lowers lipid peroxidation (20). In humans, it has been reported that treatment with fenugreek induces hypocholesterolemia and hypoglycemia $(15,18)$. Fenugreek seeds have also been experimentally shown to protect against breast and colon cancer $(21,22)$. Although hepatoprotective and antioxidant properties of fenugreek in different experimental models have been reported $(13,23,24)$, the protective role of fenugreek leaves against $\mathrm{Cd}$ toxicity has not been investigated in animal models or cell lines. The present study investigated the protective effect of fenugreek leaf extract (FLE) against Cd-induced cytotoxicity and whole genome transcription (transcriptome) in cadmium chloride $\left(\mathrm{CdCl}_{2}\right)$-treated normal rat liver cells.

\section{Materials and methods}

Chemicals. F12K medium, penicillin-streptomycin antibiotic solution (100X), fetal bovine serum (FBS), $0.25 \%$ Trypsin-EDTA solution, phosphate buffer solution (PBS), $0.25 \%$ Trypsin-EDTA solution and $\mathrm{CdCl}_{2}$ were obtained from Sigma-Aldrich (St. Louis, MO, USA). The dried fenugreek leaf powder was purchased from a local Indian store (Tallahassee, FL, USA). The 3'IVT Express kit and RG230 PM whole genome microarray analysis kit were purchased from Affymetrix (Thermo Fisher Scientific, Inc., Santa Clara, CA, USA). The RNeasy kit was purchased from Qiagen, Inc. (Germantown, MD, USA). Crystal violet, 25\% glutaraldehyde, sodium monophosphate and $95 \%$ ethanol were purchased from VWR International (Suwanee, GA, USA).

Maintenance of the cell line. The CRL1439 rat normal liver epithelial cell line was purchased from American Type Culture Collection (ATCC, Manassas, VA, USA). The supplied frozen cells were cultured according to ATCC protocols. The cells were grown in F12K medium containing $2 \mathrm{mM}$ L-glutamine, supplemented with $10 \% \mathrm{FBS}, 100 \mathrm{U} / \mathrm{ml}$ penicillin, $100 \mu \mathrm{g} / \mathrm{ml}$ streptomycin and $0.25 \mu \mathrm{g} / \mathrm{ml}$ amphotericin in T-75 $\mathrm{cm}^{2}$ flasks (Corning Incorporated, Corning, NY, USA), in a humidified $5 \% \mathrm{CO}_{2}$ incubator at $37^{\circ} \mathrm{C}(\mathrm{NuAire}$ Laboratory Equipment, Plymouth, MN, USA).

FLE preparation. The FLE was prepared by mixing $0.5 \mathrm{~g}$ of fenugreek leaf powder with $10 \mathrm{ml}$ of DMSO on a shaker overnight, followed by centrifugation (Hettich Universal 320R) at $1,180 \mathrm{x} \mathrm{g}$ for $10 \mathrm{~min}$ at room temperature. The supernatant was transferred to a new tube and used for the subsequent assays.

Cell treatment. The cell viability assay was performed by plating cells at an initial density of $5 \times 10^{4}$ cells in polystyrene flat-bottomed 24-well plates and allowed to stabilize overnight in a $5 \% \mathrm{CO}_{2}$ incubator at $37^{\circ} \mathrm{C}$. The following day, the cells were treated with either 0 or $25 \mu \mathrm{M} \mathrm{CdCl}_{2}$ alone, or 5 or $50 \mu \mathrm{g} / \mathrm{ml}$ FLE alone, or were co-treated with FLE and $25 \mu \mathrm{M}$ $\mathrm{CdCl}_{2}$ at a final volume of $1 \mathrm{ml}$ in triplicate wells for $48 \mathrm{~h}$ at $37^{\circ} \mathrm{C}$. In the co-treated group, the cells were pretreated with 5 or $50 \mu \mathrm{g} / \mathrm{ml}$ of FLE for 2 or $4 \mathrm{~h}$ prior to adding $25 \mu \mathrm{M} \mathrm{CdCl}_{2}$.

Morphology. At the end of the treatment, the morphology of the untreated control cells, the cells treated with $\mathrm{CdCl}_{2}$ alone or FLE alone, and the $\mathrm{FLE}+\mathrm{CdCl}_{2}$ co-treated liver cells were observed under a phase-contrast microscope, and images were captured with a Kodak digital camera (Kodak, Rochester, NY, USA) with $3 \mathrm{x}$ under the Nikon Diaphot phase contrast microscope (Nikon Corporation, Tokyo, Japan) with a 10X objective.

Evaluation of cell viability. The cell viability assay was performed according to a previous study (25) using a crystal violet assy. The cell plates were read in a plate reader (BioTek EL800; BioTek Instruments, Inc., Winooski, VT, USA) at $450 \mathrm{~nm}$.

RNA isolation, quantification and analysis. The transcriptome array analysis was performed by plating cells at an initial density of $1.95 \times 10^{6}$ cells in polystyrene flat-bottomed T-75 $\mathrm{cm}^{2}$ culture flask, with the cells allowed to stabilize overnight in a $5 \% \mathrm{CO}_{2}$ incubator at $37^{\circ} \mathrm{C}$. The following day, the cells were treated with 0 or $25 \mu \mathrm{M} \mathrm{CdCl}_{2}$ alone, or $5 \mu \mathrm{g} / \mathrm{ml} \mathrm{FLE}$ alone, or were co-treated with $5 \mu \mathrm{g} / \mathrm{ml} \mathrm{FLE}$ and $25 \mu \mathrm{M} \mathrm{CdCl}_{2}$ at a final volume of $10 \mathrm{ml}$, in triplicate flasks for each treatment, for $6 \mathrm{~h}$. The co-treated group flasks were pretreated with FLE for $4 \mathrm{~h}$ prior to treatment with $\mathrm{CdCl}_{2}$. At the end of the treatment, the cells were washed with PBS and trypsinized. The cells were centrifuged at $500 \mathrm{x} \mathrm{g}$ for $5 \mathrm{~min}$ at room temperature and the cell pellets were stored at $-80^{\circ} \mathrm{C}$ until further use in transcriptome (microarray) analysis.

Total RNA was isolated from the cells according to the Qiagen RNeasy kit protocol. The concentration of RNA was measured with a Nanodrop 2000 spectrophotometer (Nanodrop; Thermo Fisher Scientific, Inc.). A 250 ng sample of total RNA from each treatment group was used for cDNA synthesis (Bio-Rad MyiQ PCR machine; Bio-Rad Laboratories, Inc., Hercules, CA, USA) and converted to aRNA according to the Affymetrix 3'IVT Express kit protocol. The aRNA was synthesized, purified and hybridized with the Affymetrix Gene array strip (RG230 PM). The array contained 31,139 rat genes and was used for the transcriptome analysis. The RG230 PM rat whole genome array was blocked, hybridized, washed, stained, and images were captured according to the GeneAtlas System (Affymetrix; Thermo Fisher Scientific, Inc.) protocol. GeneAtlas system uses an array strip containing 4 microarrays and enables analysis of four samples simultaneously. This system enables whole genome transcription analysis within 2 days with $1 \mu \mathrm{g}$ total RNA. Two microarrays were used for each sample. The array strip was hybridized for 16 h. Partek ${ }^{\circledR}$ Express $^{\mathrm{TM}}$ (version 1.13.0508; Partek Inc., St. Louis, MO, USA) and Pathway Studio (version 1.1; Ariadne Genomics, Inc., Rockville, MD, USA) software were used to quantify the differentially expressed genes and metabolic pathways affected by each treatment.

\section{Results}

FLE has a protective effect on the viability of $\mathrm{CdCl}_{2}$-treated cells. Over previous years, several investigators have used various cell lines and animal models to ascertain the cytotoxicity 
and carcinogenicity of $\mathrm{Cd}$ as an environmental pollutant. Our previous investigations expanded on the scientific interest on the investigation of Cd-induced toxicity to the ameliorative effects of natural and synthetic compounds against the toxic effects of $\mathrm{Cd}$ in various cell lines (26-28). In the present study, the protective effects of FLE against Cd-induced toxicity in CRL 1439 normal rat liver cells were examined. The liver cells treated with $25 \mu \mathrm{M}$ $\mathrm{CdCl}_{2}$ alone for $48 \mathrm{~h}$ exhibited a significant $(\mathrm{P}<0.01)$ decrease in cell viability $(35.8 \pm 4.1 \%)$, compared with that of the control cells (100\%; Fig. 1). The cells pretreated with FLE prior to $\mathrm{CdCl}_{2}$ treatment had viabilities of $80.0 \pm 1.3 \%(50 \mu \mathrm{g} / \mathrm{ml} ; 2 \mathrm{~h} \mathrm{pre})$, $81.6 \pm 1.4 \%(5 \mu \mathrm{g} / \mathrm{ml}, 2 \mathrm{~h}$ pre $), 88.5 \pm 0.9 \%(50 \mu \mathrm{g} / \mathrm{ml}, 4 \mathrm{~h}$ pre $)$, and $102 \pm 3.8 \%(5 \mu \mathrm{g} / \mathrm{ml}, 4 \mathrm{~h}$ pre), respectively, compared with that in the $25 \mu \mathrm{M} \mathrm{CdCl}_{2}$ alone-treated cells $(35.8 \pm 4.1 \%)$, as shown in Fig. 1. Treatment of the cells with either 5 or $50 \mu \mathrm{g} / \mathrm{ml}$ FLE alone had no significant effect on the cell viability (Fig. 1). These results suggested that FLE had a protective effect against Cd-induced toxicity in liver cells.

FLE has a protective effect against morphological changes of cells induced by $\mathrm{CdCl}_{2}$. The morphological changes in the $\mathrm{CdCl}_{2}$-treated cells were examined and compared with those in the untreated control cells. The control cells were diamond in shape with extensions (Fig. 2A). By contrast, the cells treated with $\mathrm{CdCl}_{2}$ alone exhibited a loss of extensions and the cells became round in shape (Fig. 2B). The cells pretreated with FLE followed by $\mathrm{CdCl}_{2}$ treatment exhibited a morphology similar to that of the control cells (Fig. 2C). The FLE alone-treated cells were diamond in shape with extensions (Fig. 2D). These results indicated that FLE protected the cells from $\mathrm{Cd}$-induced morphological alterations.

\section{RG230 PM whole genome microarray analysis}

Differentially expressed genes. The whole genome microarray was performed using Affymetrix RG230 PM and the data were analyzed using Partek Express software to quantify differentially expressed genes. The differential expression of genes in each treatment group is shown in Fig. 3. The differential expression of genes was based on a 2-fold change, compared with the expression in the control cells. The numbers of upregulated and downregulated genes in each treatment group are shown in Table I. In the cells treated with $\mathrm{Cd}$ alone, 185 genes of the 31,139 total genes in the rat genome array were differentially expressed. Of these differentially expressed genes, 61 were upregulated and 124 genes were downregulated, respectively, compared with the control cells (Table I). In the cells pretreated with FLE for $4 \mathrm{~h}$ followed by $\mathrm{CdCl}_{2}, 342$ genes were modulated, of which 180 genes were upregulated and 162 genes were downregulated, compared with the control cells (Table I). In the FLE alone-treated cells, 108 genes were modulated, of which 77 genes were upregulated and 31 genes were downregulated, compared with the control cells (Table I).

The percentage of affected genes and their ascribed functions in the $\mathrm{Cd}$ alone-treated cells are shown in Fig. 4. In total, $37 \%$ of these genes have been shown to have binding activity, whereas $26 \%$ genes have catalytic activity. These two functions accounted for $>50 \%$ of the total affected genes present in the $\mathrm{CdCl}_{2}$ alone-treated cells. The remaining $37 \%$ of the genes were involved in transporter activity (9\%), antioxidant activity (7\%), protein binding transcription factor activity

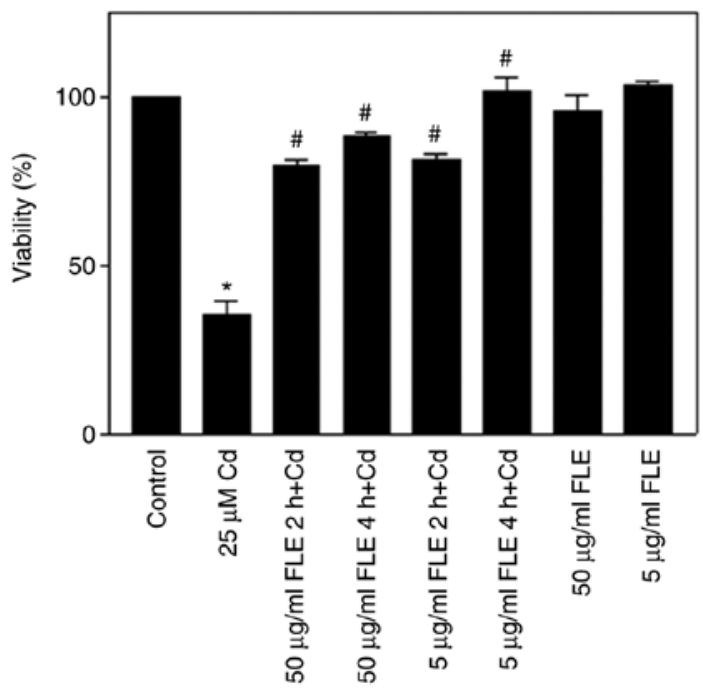

Figure 1. Protective effect of FLE on the viability of $\mathrm{CdCl}_{2}$-treated cells. The cells were treated with $\mathrm{CdCl}_{2}$ for $48 \mathrm{~h}$ with or without FLE pretreatment and viability was measured using a crystal violet assay $(n=3)$. $P<0.05$, compared with the control; ${ }^{\#} \mathrm{P}<0.05$, compared with $\mathrm{CdCl}_{2}$ alone. Statistical analysis performed using Dunnett's multiple comparison test. FLE, fenugreek leaf extract; $\mathrm{CdCl}_{2}$, cadmium chloride.
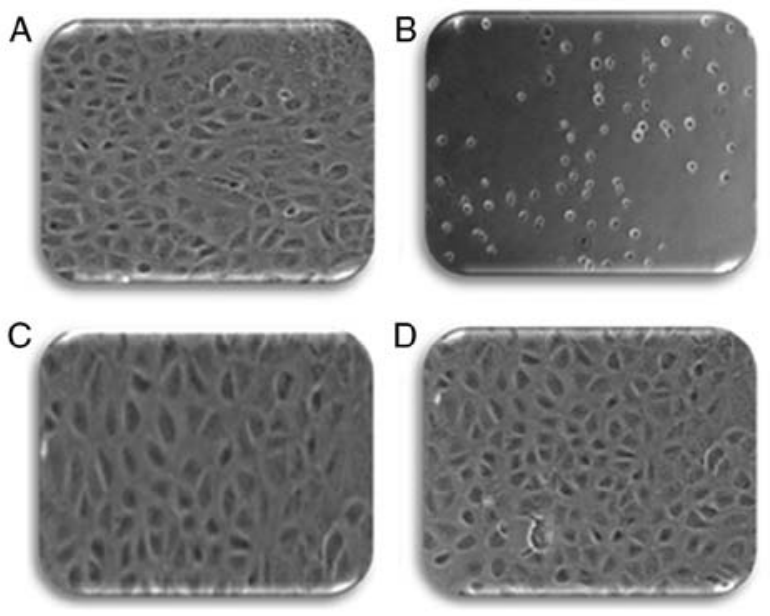

Figure 2. Protective effect of FLE on the morphological changes of $\mathrm{CdCl}_{2}$-treated cells. The cells were treated (A) without $\mathrm{CdCl}_{2}$, or treated with (B) $25 \mu \mathrm{M} \mathrm{CdCl}_{2}$ for $48 \mathrm{~h}$, (C) pretreated with FLE $(5 \mu \mathrm{g} / \mathrm{ml})$ for $4 \mathrm{~h}$ followed by $\mathrm{CdCl}_{2}$ for $48 \mathrm{~h}$, or (D) treated with FLE $(5 \mu \mathrm{g} / \mathrm{ml})$ alone. Images were captured with a Kodak digital camera under the Nikon Diaphot phase contrast microscope (magnification, x10). FLE, fenugreek leaf extract; $\mathrm{CdCl}_{2}$, cadmium chloride.

(7\%), molecular transducer activity (5\%), nucleic acid binding transcription factor activity (5\%), electron carrier activity (2\%) and receptor activity $(2 \%)$.

The percentage of affected genes and their function in the cells pretreated with FLE for $4 \mathrm{~h}$ followed by $\mathrm{CdCl}_{2}$ are shown in Fig. 5. Specifically, 50\% of the genes have been shown to have binding activity, whereas $20 \%$ have catalytic activity. The remaining $30 \%$ of the genes were involved in several functional activities, including molecular transducer (7\%), transporter (7\%), and electron carrier (4\%), and enzyme regulator (3\%), nucleic acid binding transcription factor (3\%), receptor (3\%) and structural molecule (3\%). 


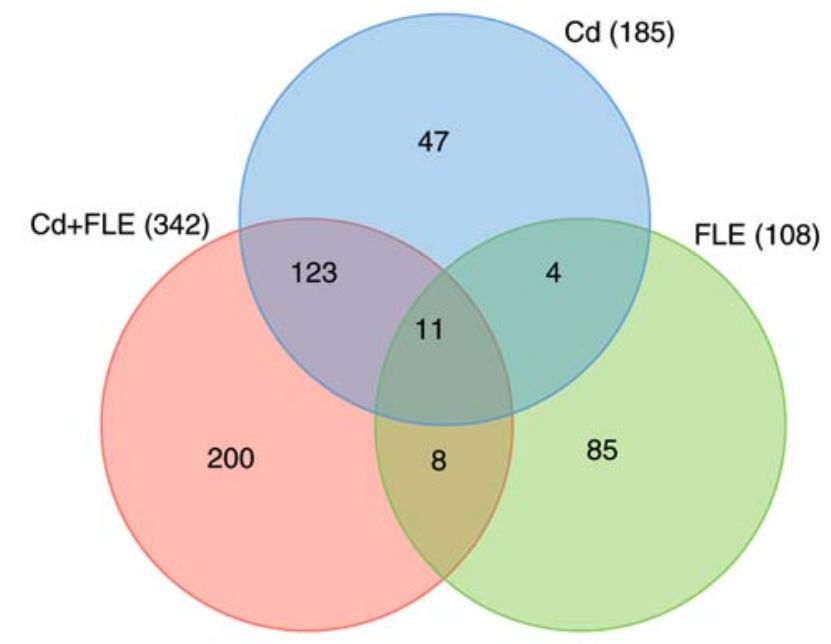

Figure 3. Differentially expressed genes in different treatment groups. The cells were treated with $\mathrm{CdCl}_{2}$ alone, FLE alone, or pretreated with FLE for $4 \mathrm{~h}$ followed by $\mathrm{CdCl}_{2}$ for $6 \mathrm{~h}$. The total RNA isolated from these treatment groups was subjected to whole genome microarray analysis using an Affymetrix RG230 PM array and the data were analyzed using Partek Express software to quantify differentially expressed genes with a fold change range of $>2$ and $<-2$, compared with the control. The total number of differentially expressed genes in each treatment group is indicated in parentheses. FLE, fenugreek leaf extract; $\mathrm{CdCl}_{2}$, cadmium chloride.

The names of the top 10 upregulated genes, percentage fold upregulation, and function of each of the upregulated genes in the $\mathrm{Cd}$ alone-treated cells are shown in Table II. The genes were $\gamma$-2a immunoglobulin heavy chain, similar to RIKEN cDNA 1700016G05, transmembrane protein 106B, YY1 transcription factor glycosyltransferase 25 domain containing 1 , prefoldin subunit 5 , transcription factor AP- $2 \alpha$, phosphatidic acid phosphatase type 2B, selenoprotein W1 (SelW), and spermatogenesis-associated, serine-rich 2-like.

In the cells pretreated with FLE for $4 \mathrm{~h}$ followed by $\mathrm{CdCl}_{2}$, the top 10 upregulated gene names, percentage fold upregulation and function of each gene are shown in Table III. The upregulated genes were $\gamma$-2a immunoglobulin heavy chain, BMP-binding endothelial regulator, similar to RIKEN cDNA 1700016G05, periostin, osteoblast specific factor, chemokine (C-X-C motif) ligand 12 (stromal cell-derived factor 1), fibromodulin, activating transcription factor 5, ribosomal L24 domain containing 1, calpastatin, and $\mathrm{SH} 3$ domain binding glutamic acid-rich protein like.

The percentage fold repression and functions of the genes in $\mathrm{Cd}$ alone-treated cells are shown in Table IV. The top 10 genes observed were aldehyde oxidase 1, solute carrier family 7 (cationic amino acid transporter, $\mathrm{y}^{+}$system), member 11, heme oxygenase (decycling) 1, ATP-binding cassette, sub-family C (CFTR/MRP), member 4, solute carrier family 39 (iron-regulated transporter), member 1, chemokine (C-C motif) ligand 7, sulfiredoxin 1 homolog (S. cerevisiae), monoamine oxidase A, catalase, and adenosine monophosphate deaminase 3 .

In the cells pretreated with FLE for $4 \mathrm{~h}$, followed by $\mathrm{CdCl}_{2}$ treatment, the top 10 downregulated gene names, fold downregulation and function of each gene are shown in Table V. The genes with the highest levels of downregulation were metallothionein $1 \mathrm{a}$, metallothionein $2 \mathrm{~A}$, aldehyde oxidase 1 , heme oxygenase (decycling) 1, solute carrier family 7
Table I. Number of differentially expressed genes in the treatment groups.

\begin{tabular}{lccr}
\hline Fold change range & $\mathrm{CdCl}_{2}$ & $\mathrm{CdCl}_{2}+\mathrm{FLE}$ & FLE \\
\hline $1-2$ & 61 & 180 & 77 \\
$<-15$ & 1 & 1 & 0 \\
$>-14-<-10$ & 2 & 2 & 0 \\
$>-10-<-2$ & 121 & 159 & 31 \\
\hline
\end{tabular}

$\mathrm{CdCl}_{2}$, cadmium chloride; FLE, fenugreek leaf extract.

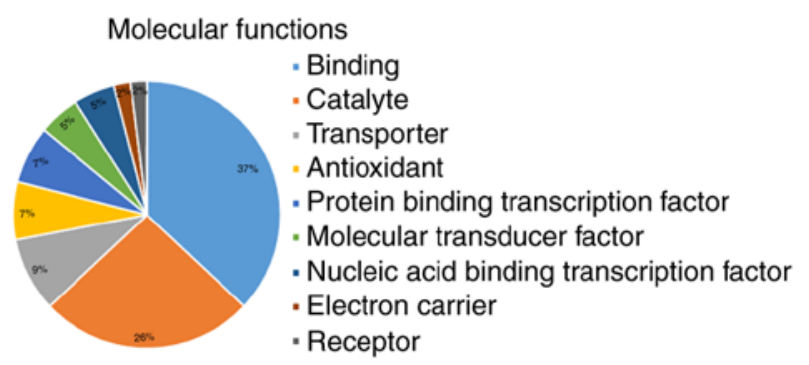

Figure 4. Percentages of genes for each molecular function in $\mathrm{CdCl}_{2}$ alone-treated cells. The cells were treated with $\mathrm{CdCl}_{2}$ alone for $6 \mathrm{~h}$ and isolated total RNA was subjected to whole genome microarray analysis using an Affymetrix RG230 PM array, with data analyzed using Partek Express software to show the percentage of genes for each molecular function. $\mathrm{CdCl}_{2}$, cadmium chloride.

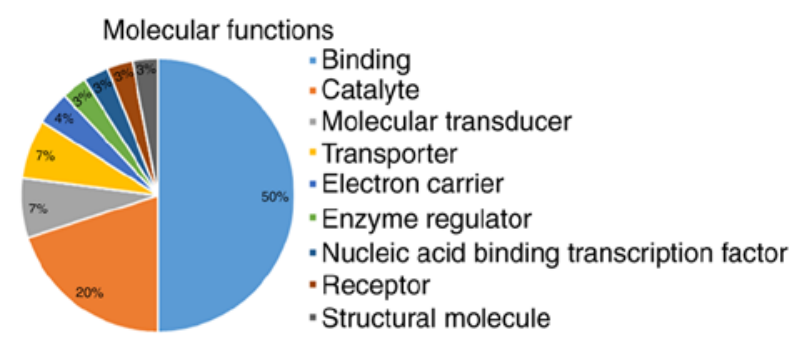

Figure 5. Percentage of genes for each molecular function in cells pretreated with FLE followed by treatment with $\mathrm{CdCl}_{2}$. The cells were pretreated with FLE for $4 \mathrm{~h}$ followed by $\mathrm{CdCl}_{2}$ for $6 \mathrm{~h}$, and total RNA was isolated and subjected to whole genome microarray analysis using an Affymetrix RG230 PM array. The data were analyzed using Partek Express software to show the percentage of genes for each molecular function. FLE, fenugreek leaf extract; $\mathrm{CdCl}_{2}$, cadmium chloride.

(cationic amino acid transporter, $\mathrm{y}^{+}$system), member 11, ectonucleoside triphosphate diphosphohydrolase 5, ATP-binding cassette, sub-family C (CFTR/MRP), member 4, Coenzyme Q6 homolog (yeast), zinc finger, AN1-type domain 2A, and glutamate cysteine ligase, modifier subunit. Therefore, the Affymetrix RG230 PM whole genome microarray data analysis clearly showed the differential genes expression in cells treated with $\mathrm{Cd}$ alone and in those co-treated with FLE and $\mathrm{CdCl}_{2}$.

Pathways affected by $\mathrm{CdCl}_{2}$ and modulation by FLE in rat liver cells. Ariadne software was used to establish the metabolic pathways affected in each treatment group. The most prominent upregulated pathways and percentage of genes 
Table II. Prominently upregulated genes in cadmium chloride-treated cells.

\begin{tabular}{lll}
\hline Gene & Fold change & \\
\hline$\gamma$-2a immunoglobulin heavy chain & 7.34 & Function \\
Similar to RIKEN cDNA 1700016G05 & 4.28 & Antigen binding \\
Transmembrane protein 106B & 3.1 & Serine-type endopeptidase activity \\
YY1 transcription factor & 2.76 & Uncharacterized \\
Glycosyltransferase 25 domain containing 1 & 2.53 & DNA binding, metal ion binding \\
& & Transferase activity, procollagen \\
Prefoldin subunit 5 & 2.46 & galactosyltransferase activity \\
Transcription factor activator protein-2, $\alpha$ & 2.37 & Unfolded protein binding \\
& & RNA polymerase II core promoter \\
& & sequence-specific, DNA binding, chromatin \\
& & binding, RNA polymerase II core promoter \\
proximal region sequence-specific, DNA & binding transcription factor activity involved in \\
Phosphatidic acid phosphatase type 2B & & negative regulation of transcription \\
Selenoprotein W1 & & Integrin binding, lipid phosphatase activity \\
Spermatogenesis associated, serine-rich 2-like & 2.32 & Antioxidant activity, selenium binding \\
\hline
\end{tabular}

Table III. Prominently upregulated genes in cells pretreated with fenugreek leaf extract followed by cadmium chloride treatment.

\begin{tabular}{lcl}
\hline Gene & Fold change & \multicolumn{1}{c}{ Function } \\
\hline$\gamma$-2a immunoglobulin heavy chain & 6.76 & Antigen binding \\
BMP-binding endothelial regulator & 5.01 & Inhibitor of bone morphogenetic protein function \\
Similar to RIKEN cDNA 1700016G05 & 4.41 & Serine-type endopeptidase activity \\
Periostin, osteoblast specific factor & 3.69 & Heparin binding \\
Chemokine (C-X-C motif) ligand 12 & 3.57 & Chemokine receptor binding, chemokine activity \\
Fibromodulin & 3.48 & Collagen binding \\
Activating transcription factor 5 & 3.41 & Heat shock protein binding \\
Ribosomal L24 domain containing 1 & 3.3 & Ribosome biogenesis \\
Calpastatin & 3.16 & Calcium-dependent cysteine-type endopeptidase \\
& & inhibitor activity, protease binding \\
SH3 domain binding glutamic acid-rich & 3.12 & Electron carrier activity, protein disulfide oxidore \\
protein like & & ductase activity \\
\hline
\end{tabular}

affected in each pathway from the $\mathrm{CdCl}_{2}$ alone-treated cells and the cells pretreated with FLE for $4 \mathrm{~h}$ followed by $\mathrm{CdCl}_{2}$ are shown in Table VI. In the $\mathrm{CdCl}_{2}$ alone-treated cells, the most upregulated pathways were ribosome synthesis, valine, leucine and isoleucine biosynthesis pathway, DNA replication pathway, mismatch repair pathway, ubiquinone and terpenoid-quinone biosynthesis pathway, TCA cycle pathway, Parkinson's disease pathway, sulfur metabolism pathway, RNA transport pathway, and vitamin B6 metabolism (Table VI). The following pathways were the most affected in the cells treated with FLE for $4 \mathrm{~h}$ followed by $\mathrm{CdCl}_{2}$ : Ribosome synthesis, Valine, leucine and isoleucine biosynthesis, DNA replication, Ubiquinone and terpenoid-quinone biosynthesis, TCA cycle, Parkinson's disease, RNA transport, thiamine metabolism, pantothenate and CoA biosynthesis, and sulfur relay system (Table VI).

The most markedly downregulated pathways and percentage of genes affected in each pathway in the $\mathrm{CdCl}_{2}$ alone-treated cells and in the cells pretreated with FLE for $4 \mathrm{~h}$ followed by $\mathrm{CdCl}_{2}$ are shown in Table VII. In the $\mathrm{CdCl}_{2}$ alone-treated cells, the most downregulated pathways were D-arginine and D-ornithine metabolism, bile acid biosynthesis, acid secretion, amino sugars metabolism, butirosin and neomycin biosynthesis, caffeine metabolism, amino sugars and nucleotide sugar metabolism, pentose and glucuronate, ascorbate and alderate metabolism, and drug metabolism. In the cells pretreated with FLE for $4 \mathrm{~h}$ followed by $\mathrm{CdCl}_{2}$ treatment, genes involved in the metabolism of xenobiotics by cytochrome $\mathrm{P} 450$, steroid hormone biosynthesis and retinol metabolism pathways were affected (Table VII).

\section{Discussion}

The marked increase of $\mathrm{Cd}$ in the environment is partially due to natural and anthropogenic activities. Exposure to this metal 
Table IV. Prominently downregulated genes in cadmium chloride-treated cells.

\begin{tabular}{|c|c|c|}
\hline Gene name & Fold change & Function \\
\hline Aldehyde oxidase 1 & -10.48 & NAD binding, electron carrier activity, iron ion binding \\
\hline $\begin{array}{l}\text { Solute carrier family } 7 \text { (cationic amino acid } \\
\text { transporter, } \mathrm{y}^{+} \text {system), member } 11\end{array}$ & -9.2 & Amino acid transmembrane transporter activity \\
\hline Heme oxygenase (decycling) 1 & -6.24 & $\begin{array}{l}\text { Enzyme binding, heme binding, metal ion binding, } \\
\text { protein binding, heme oxygenase activity, oxidoreductase } \\
\text { activity }\end{array}$ \\
\hline $\begin{array}{l}\text { ATP-binding cassette, sub-family C } \\
\text { (CFTR/MRP), member } 4\end{array}$ & -6.12 & $\begin{array}{l}\text { ATP binding, enzyme binding, chloride channel inhibitor } \\
\text { activity, transmembrane transporter activity }\end{array}$ \\
\hline $\begin{array}{l}\text { Solute carrier family } 39 \text { (iron-regulated } \\
\text { transporter), member } 1\end{array}$ & -4.7 & Iron ion transmembrane transporter activity \\
\hline Chemokine (C-C motif) ligand 7 & -4.14 & $\mathrm{C}-\mathrm{C}$ chemokine receptor activity \\
\hline Sulfiredoxin 1 homolog $(S$. cerevisiae $)$ & -4.1 & $\begin{array}{l}\text { ATP binding, antioxidant activity, oxidoreductase activity, } \\
\text { sulfiredoxin activity }\end{array}$ \\
\hline Monoamine oxidase A & -4.07 & $\begin{array}{l}\text { Flavin adenine dinucleotide binding, oxidoreductase activity, } \\
\text { serotonin binding }\end{array}$ \\
\hline Catalase & -3.58 & $\begin{array}{l}\text { NADP binding, aminoacylase activityaminoacylase activity, } \\
\text { antioxidant activity, heme binding, oxidoreductase activity, } \\
\text { receptor binding }\end{array}$ \\
\hline Adenosine monophosphate deaminase 3 & -3.46 & AMP deaminase activity, metal ion binding \\
\hline
\end{tabular}

Table V. Prominently downregulated genes in cells pretreated with fenugreek leaf extract followed by cadmium chloride treatment.

\begin{tabular}{|c|c|c|}
\hline Gene & Fold change & Function \\
\hline Metallothionein 1a & -59.21 & Cadmium ion binding, zinc ion binding \\
\hline Metallothionein 2A & -11.63 & Cadmium ion binding, zinc ion binding \\
\hline Aldehyde oxidase 1 & -10.03 & NAD binding, electron carrier activity, iron ion binding \\
\hline Heme oxygenase (decycling) 1 & -9.72 & $\begin{array}{l}\text { Enzyme binding, heme binding, metal ion binding, protein } \\
\text { binding, heme oxygenase activity, oxidoreductase activity }\end{array}$ \\
\hline $\begin{array}{l}\text { Solute carrier family } 7 \text { (cationic amino } \\
\text { acid transporter, } \mathrm{y}^{+} \text {system), member } 11\end{array}$ & -7.28 & Amino acid transmembrane transporter activity \\
\hline $\begin{array}{l}\text { Ectonucleoside triphosphate } \\
\text { diphosphohydrolase } 5\end{array}$ & -6.53 & $\begin{array}{l}\text { Guanosine-diphosphatase activity, uridine-diphosphatase } \\
\text { activity }\end{array}$ \\
\hline $\begin{array}{l}\text { ATP-binding cassette, sub-family C } \\
\text { (CFTR/MRP), member } 4\end{array}$ & -6.42 & ATP binding \\
\hline Coenzyme Q6 homolog (yeast) & -5.05 & $\begin{array}{l}\text { Flavin adenine dinucleotide binding, oxidoreductase activity, } \\
\text { monooxygenase activity }\end{array}$ \\
\hline Zinc finger, AN1-type domain $2 \mathrm{~A}$ & -5 & Zinc ion binding \\
\hline Glutamate cysteine ligase, modifier subunit & -4.97 & $\begin{array}{l}\text { Glutamate-cysteine ligase activity, protein heterodimerization } \\
\text { activity }\end{array}$ \\
\hline
\end{tabular}

poses a serious threat to human health. Cd passes through alveolar cells to enter the blood and is eventually deposited into the liver and kidneys due to their high content of metal-binding metallothionein proteins $(29,30)$. As Cd cannot be metabolically degraded or transform to lesser toxic species, this leads to its long-term storage and accumulation in the higher micromolar range in tissues of occupational and non-occupationally exposed populations. Although, various mechanisms for $\mathrm{Cd}$ toxicity have been suggested, the manifestations $\mathrm{Cd}$ toxicity are mostly due to oxidative stress $(11,31)$. Oxidative stress leads to the damage of important biomolecules, including DNA, protein and lipids, in the organs with potential effects on the whole organism $(11,12,32)$. This damage to biomolecules may be a key pathophysiological factor in liver diseases, including chronic liver injury, hepatic inflammation, fibrosis, and hepatocellular carcinoma $(33,34)$. Various natural plant compounds 
Table VI. Percentage of altered genes in the most prominently upregulated pathways.

\begin{tabular}{lcc}
\hline & $\begin{array}{c}\mathrm{CdCl}_{2} \text { alone-treated } \\
\text { cells (\%) }\end{array}$ & $\begin{array}{c}\text { Cells pretreated with FLE } \\
\text { followed by CdCl }{ }_{2} \text { treatment }(\%)\end{array}$ \\
\hline Ribosome & 87 & 92 \\
Valine, leucine and isoleucine biosynthesis & 85 & 71 \\
DNA replication & 83 & 66 \\
Mismatch repair & 78 & - \\
Ubiquinone and other terpenoid-quinone biosynthesis & 75 & 75 \\
TCA cycle & 75 & 75 \\
Parkinson's disease & 71 & - \\
Sulfur metabolism & 71 & 64 \\
RNA transport & 70 & - \\
Vitamin B6 metabolism & 67 & 67 \\
Thiamine metabolism & - & 65 \\
Pantothenate and CoA biosynthesis & - & 63 \\
Sulfur relay system & - & \\
\hline
\end{tabular}

$\mathrm{CdCl}_{2}$, cadmium chloride; FLE, fenugreek leaf extract.

Table VII. Percentage of altered genes in most prominently downregulated pathways.

Name of pathway

$\mathrm{CdCl}_{2}$ alone-treated cells $(\%)$
Cells pretreated with

FLE followed by $\mathrm{CdCl}_{2}$ treatment (\%)

D-Arginine and D-Ornithine metabolism

$\begin{array}{rc}100 & 100 \\ 89 & 89 \\ 88 & 88 \\ 86 & - \\ 86 & 86 \\ 80 & - \\ 79 & - \\ & \\ 78 & 83 \\ 65 & 75 \\ 27 & 31 \\ - & 84 \\ - & 80 \\ - & 80\end{array}$

Primary bile acid biosynthesis

89

Collecting duct acid secretion

88

Amino sugars metabolism

86

Butirosin and neomycin biosynthesis

Amino sugars and nucleotide amino sugars and

Pentose and glucuronate interconversions

Ascorbate and alderate metabolism

31

Metabolism of xenobiotics by cytochrome p450

Steroid hormone biosynthesis

Retinol metabolism

$\mathrm{CdCl}_{2}$, cadmium chloride; FLE, fenugreek leaf extract.

and synthetic compounds have been tested to reduce the toxic effect of $\mathrm{Cd}$ in cell lines or animal models $(27,28,35,36)$. In the present study, the protective effect of FLE on the viability, morphology and whole genome expression were investigated in $\mathrm{CdCl}_{2}$-treated CRL1439 normal rat liver cells.

In the in vitro experiments performed in the present study, the cells were treated with $25 \mu \mathrm{M} \mathrm{CdCl}_{2}$ for $48 \mathrm{~h}$. This treatment caused a significant decrease $(35.8 \pm 4.1 \%)$ in cell viability (Fig. 1) and altered the morphology of the liver cells (Fig. 2B), compared with the untreated control cells (Figs. 1 and 2A). However, FLE pretreatment significantly reversed the altered morphology caused by $\mathrm{Cd}$ and increased the viability of the $\mathrm{CdCl}_{2}$-treated rat liver cells (Fig. 1). Pretreatment with $5 \mu \mathrm{g} / \mathrm{ml}$ of FLE for $4 \mathrm{~h}$ led to the highest increase in viability and reduction in altered morphology caused by $\mathrm{CdCl}_{2}$ treatment in the rat liver cells (Figs. 1 and 2C). Treatment with $50 \mu \mathrm{g} / \mathrm{ml}$ FLE alone showed marginal toxicity towards the cells (Fig. 1). However, $5 \mu \mathrm{g} / \mathrm{ml}$ FLE alone had no adverse effects on the cell viability and/or morphology (Figs. 1 and 2B). Therefore, pretreatment of cells with $5 \mu \mathrm{g} / \mathrm{ml}$ of FLE for $4 \mathrm{~h}$, followed by $25 \mu \mathrm{M} \mathrm{CdCl}_{2}$ for $48 \mathrm{~h}$ was used for whole genome expression analysis. Fenugreek plant extracts 
have been reported to contain alkaloids (37), flavonoids (38) and salicylate (39), which exhibit antioxidant properties. The active components and the biological activities of the isolates from fenugreek with antioxidant and anti-inflammatory activities have been reported (40). A previous study showed that fenugreek leaves contain alkaloids, cardiac glycosides and phenols (41). It has also been shown that fenugreek leaves exhibit anti-oxidant properties against $\mathrm{H}_{2} \mathrm{O}_{2}$ - and $\mathrm{CCl}_{4}$-induced hepatotoxicity (23). It is possible that the FLE exerts its protective effects against the oxidative stress caused by $\mathrm{Cd}$ and provides protection by the increase in cell viability and inhibition of altered morphology.

To discern the genes and pathways affected by $25 \mu \mathrm{M}$ $\mathrm{CdCl}_{2}$ treatment and modulation by FLE pretreatment, analysis of the whole genome expression on the Affymetrix Gene array strip RG230 PM was performed using GeneAtlas system. It was observed that, in cells treated with $\mathrm{CdCl}_{2}$ alone, more genes in the rat genome RG230 PM Array were downregulated (124 genes) than upregulated (61 genes), whereas in cells pretreated with FLE followed by $\mathrm{CdCl}_{2}$, more genes were upregulated (180 genes) than downregulated (162 genes), which showed the modulation of gene expression by FLE (Table I). It was also observed in the $\mathrm{Cd}$ alone-treated cells, that 47 unique genes were expressed, whereas 200 unique genes were expressed in the FLE co-treated cells (Fig. 3). In addition, as shown in Fig. 3, 123 genes were expressed in the cells treated with $\mathrm{Cd}$ alone and the cells pretreated with FLE followed by $\mathrm{CdCl}_{2}$ (Fig. 3).

The percentage of differentially regulated genes responsible for each important metabolic function indicated that, in the $\mathrm{Cd}$ alone-treated cells, 37 and $26 \%$ of the genes were involved in the binding and catalytic activities, respectively (Fig. 4). In the cells pretreated with FLE followed by $\mathrm{CdCl}_{2}, 50$ and $20 \%$ of genes were involved in the binding and catalytic activity functions, respectively (Fig. 5). The induced expression of genes with binding function by FLE pretreatment may be as a result of a reduction in oxidative stress caused by $\mathrm{Cd}$, which was reflected in the observed improved viability of the Cd-treated cells (Fig. 2). This observation is in agreement with an earlier report, which also showed that FLE exhibited anti-oxidant properties against $\mathrm{H}_{2} \mathrm{O}_{2}$ - and $\mathrm{CCl}_{4}$-induced hepatotoxicity (23).

The top 10 upregulated genes in the Cd-treated cells (Table II) were $\gamma$-2a immunoglobulin heavy chain, similar to RIKEN cDNA 1700016G05, transmembrane protein 106B, YY1 transcription factor, glycosyltransferase 25 domain containing 1 , prefoldin subunit 5 , transcription factor AP-2, $\alpha$, phosphatidic acid phosphatase type 2 B, SelW1, and spermatogenesis associated, serine-rich 2-like. The common $\gamma$-chain $(\gamma c)$ is central in signaling by interleukin-2 and other $\gamma$ c-dependent cytokines (42). YY1 is known to inhibit the activation of P53 in response to genotoxic stress (43). Previously, it was shown that primary normal human bronchial epithelial cells incubated with $15 \mu \mathrm{g} / \mathrm{l} \mathrm{Cd}$ (II) affected YY1-stress response-related transcription factor (44). SelW is a selenocysteine-containing protein with a low molecular weight, indicating the redox activity involved in the antioxidant response. Previously, it was reported that the mRNA expression level of SelW was sharply increased by 4.98 -fold in the liver of $0.5 \mathrm{ppm}$ cadmium-treated goldfish, compared with that in the control (45). The oxidative stress induced by metal exposure leads to the activation of transcription factors, including activator protein (AP)-1 and nuclear factor- $\kappa \mathrm{B}$. Previously, it was also shown that cells exposed to cadmium led to a significant activation of AP-1 and all three members of the mitogen-activated protein kinase family $(46,47)$. Unconventional prefoldin RPB5 interactor has been identified as a transcriptional repressor, which binds RNA polymerase II through interaction with the RPB5/POLR2E subunit (48). In the present study, the activation of $\gamma$-2a immunoglobulin heavy chain, YY1, SelW, AP-2, and prefoldin RPB5 interactor clearly indicated that $\mathrm{CdCl}_{2}$ treatment induced oxidative stress in the rat liver cells.

In the present study, the genes that were downregulated in Cd-treated cells are listed in Table IV. Specifically, they were aldehyde oxidase 1, solute carrier family 7 (cationic amino acid transporter, $\mathrm{y}^{+}$system), member 11 , heme oxygenase (decycling) 1, ATP-binding cassette, sub-family C (CFTR/MRP), member 4, solute carrier family 39 (iron-regulated transporter), member 1 , chemokine (C-C motif) ligand 7, sulfiredoxin 1 homolog (S. cerevisiae), monoamine oxidase A, catalase, and adenosine monophosphate deaminase 3. A previous in vivo study indicated that the heme oxygenase-1 and monoamine oxidase enzyme activities were decreased in the liver and kidneys of male Wistar albino rats exposed to 1, 2 and $4 \mathrm{mg}$ $\mathrm{Cd}(2+) / \mathrm{kg}$ body weight for 1 and 3 months (49). The decrease in the observed enzyme activities may be attributed to the downregulation of the enzymes coding gene expression. In contrast to the finding in the present study of downregulated expression of chemokine (C-C motif) ligand 7, the expression of the same gene has been reported to be upregulated in the HepG2 human hepatoma cell line following exposure to 2 and $10 \mu \mathrm{M}$ Cd using an Agilent microarray, the chemokine, C-C motif, receptor 7 (50). The difference in expression compared with the present result may be due to the $\mathrm{Cd}$ concentration used and/or to the cell type (normal vs. tumor cell line). The downregulation of catalase in Cd-treated cells in the present study was consistent with previous studies that catalase levels were markedly decreased $(\mathrm{P}<0.001)(11,51)$.

In the cells pretreated with FLE followed by $\mathrm{Cd}$, the expression of $\gamma$-2a immunoglobulin heavy chain (6.76-fold; Table II), which has antigen-binding function, was reduced compared with that in the Cd alone-treated cells (7.34-fold; Table II). A higher number of genes coding for binding and catalytic activities (50 and 20\%; Fig. 5) were expressed in the FLE pretreatment followed by Cd-treated cells, compared with the number in the Cd alone-treated cells (37 and 26\%; Fig. 4). It was also observed that the main metabolic pathways, including amino acid synthesis and DNA replication, were affected by $\mathrm{CdCl}_{2}$ treatment, and that FLE pretreatment modulated these pathway genes.

In conclusion, the results of the present study showed that FLE pretreatment conferred protection against Cd toxicity, as shown by the increased viability and inhibition of altered morphology of the normal rat liver cells. The protective potential of FLE may be attributed to modulation of the whole transcriptome, which prevented Cd-induced toxicity in the normal rat cells. Therefore, the findings from the present study suggested that the unique pharmacological properties of fenugreek leaves can be used to prevent $\mathrm{Cd}$-induced pathophysiological anomalies. 


\section{Acknowledgements}

The authors would like to thank Dr Ramesh B Badisa (College of Pharmacy and Pharmaceutical Sciences, Florida A\& MUniversity, Tallahassee, USA) and Ms Sydney Dennis (Department of Biological Sciences, Florida A\& M University, Tallahassee, USA) for making pie graphs and formatting the figures.

\section{Funding}

The present study was financially supported by the FAMU Title III, Department of Education (grant. no. DOEHBGIPO31B40108-08) and the RCMI, National Institute of Health (grant. nos. G12RR03020 and G12D007582).

\section{Availability of data and materials}

The datasets generated and analyzed during the current study are available from the corresponding author upon reasonable request.

\section{Authors' contributions}

CO, LL and VLB designed the experiments. RLL II and CAA carried out the research. CO, VLB, LL and MKF worked on the manuscript.

\section{Ethics approval and consent to participate}

Not applicable.

\section{Consent for publication}

Not applicable.

\section{Competing interests}

The authors declare that they have no competing interests.

\section{References}

1. Engström A, Michaëlsson K, Suwazono Y, Wolk A, Vahter M and Akesson A: Long-term cadmium exposure and the association with bone mineral density and fractures in a population-based study among women. J Bone Miner Res 26: 486-495, 2011.

2. Satarug S, Garrett SH, Sens MN and Sens DA: Cadmium, environmental exposure, and health outcomes. Environ Health Perspect 118: 182-190, 2010.

3. Järup L and Akesson A: Current status of cadmium as an environmental health problem. Toxicol Appl Pharmacol 238: 201-208, 2009.

4. Anetor JI: Rising environmental cadmium levels in developing countries: Threat to genome stability and health. Niger J Physio Sci 27: 103-115, 2012.

5. Nasreddine L and Parent-Massin D: Food contamination by metals and pesticides in the European Union. Should we worry? Toxicol Lett 127: 29-41, 2002.

6. Agency for Toxic Substances and Disease Registry (ATSDR): Toxicological Profile for Cadmium. Atlanta, GA: U.S. Department of Health and Human Services, Public Health Service, pp1-512, 2012.

7. International agency for research on cancer (IARC): Monographs on the Evaluation of the Carcinogenic Risks to Humans, Beryllium, Cadmium, Mercury and Exposures in the Glass Manufacturing industry. In: IARC Scientific Publications, Lyon, France, pp119-238, 1993.
8. El-Refaiy AI and Eissa FI: Histopathology and cytotoxicity as biomarkers in treated rats with cadmium and some therapeutic agents. Saudi J Biol Sci 20: 265-280, 2013.

9. Lakshmi GD, Kumar PR, Bharavi K, Annapurna P, Rajendar B, Patel PT, Kumar CS and Rao GS: Protective effect of Tribulus terrestris linn on liver and kidney in cadmium intoxicated rats. Indian J Exp Biol 50: 141-146, 2012.

10. Thompson J and Bannigan J: Cadmium: Toxic effects on the reproductive system and the embryo. Reprod Toxicol 25: 304-315, 2008.

11. Ikediobi CO, Badisa VL, Ayuk-Takem LT, Latinwo LM and West J: Response of antioxidant enzymes and redox metabolites to cadmium-induced oxidative stress in CRL-1439 normal rat liver cells. Int J Mol Med 14: 87-92, 2004.

12. Badisa VL, Latinwo LM, Odewumi CO, Ikediobi CO, Badisa RB, Brooks-Walter A, Lambert AT and Nwoga J: Cytotoxicity and stress gene microarray analysis in cadmium-exposed CRL-1439 normal rat liver cells. Int J Mol Med 22: 213-219, 2008.

13. Kaviarasan S and Anuradha CV: Fenugreek (Trigonella foenum-graecum) seed polyphenols protect liver from alcohol toxicity: A role on hepatic detoxification system and apoptosis. Pharmazie 62: 299-304, 2007.

14. Kaviarasan S, Viswanathan $P$ and Anuradha CV: Fenugreek seed (Trigonella foenum-graecum) polyphenols inhibit ethanol-induced collagen and lipid accumulation in rat liver. Cell Biol Toxicol 23: 373-383, 2007.

15. Sharma RD: Effect of fenugreek seeds and leaves on blood glucose and serum insulin responses in human subjects. Nutrition Res 6: 1353-1364, 1986.

16. Basch E, Ulbricht C, Kuo G, Szapary P and Smith M: Therapeutic applications of fenugreek. Altern Med Rev 8: 20-27, 2003.

17. Xue WL, Li XS, Zhang J, Liu YH, Wang ZL and Zhang RJ: Effect of Trigonella foenum-graecum (fenugreek) extract on blood glucose, blood lipid and hemorheological properties in streptozotocin-induced diabetic rats. Asia Pac J Clin Nutr 16 (Suppl 1): S422-S426, 2007.

18. Sharma RD, Raghuram TC and Rao NS: Effect of fenugreek seeds on blood glucose and serum lipids in type I diabetes. Eur J Clin Nutr 44: 301-306, 1990.

19. Gupta A, Gupta R and Lal B: Effect of Trigonellafoenum-graecum (fenugreek) seeds on glycaemic control and insulin resistance in type 2 diabetes mellitus: A double blind placebo controlled study. J Assoc Physicians India 49: 1057-1061, 2001.

20. Ravikumar P and Anuradha CV: Effect of fenugreek seeds on blood lipid peroxidation and antioxidants in diabetic rats. Phytother Res 13: 197-201, 1999.

21. Amin A, Alkaabi A, Al-Falasi S and Daoud SA: Chemopreventive activities of Trigonella foenum graecum (Fenugreek) against breast cancer. Cell Biol Int 29: 687-694, 2005.

22. Raju J, Patlolla JM, Swamy MV and Rao CV: Diosgenin, a steroid saponin of Trigonella foenum graecum (Fenugreek), inhibits azoxymethane-induced aberrant crypt foci formation in F344 rats and induces apoptosis in HT-29 human colon cancer cells. Cancer Epidemiol Biomarkers Prev 13: 1392-1398, 2004.

23. Meera R, Devi P, Kameswari B, Madhumitha B and Merlin NJ: Antioxidant and hepatoprotective activities of Ocimum basilicum Linn. and Trigonella foenum-graecum Linn. against $\mathrm{H}_{2} \mathrm{O}_{2}$ and CCL4 induced hepatotoxicity in goat liver. Indian J Exp Biol 47: 584-590, 2009.

24. Bajpai M, Mishra A and Prakash D: Antioxidant and free radical scavenging activities of some leafy vegetables. Int J Food Sci Nutr 56: 473-481, 2005

25. Badisa RB, Tzakou O, Couladis M and Pilarinou E: Cytotoxic activities of some Greek Labiatae herbs. Phytother Res 17: 472-476, 2003

26. Forrester LW, Latinwo LM, Fasanya-Odewumi C, Ikediobi C, Abazinge MD, Mbuya $\mathrm{O}$ and Nwoga J: Comparative studies of cadmium-induced single strand breaks in female and male rats and the ameliorative effect of selenium. Int J Mol Med 6: 449-452, 2000.

27. Odewumi CO, Badisa VL, Le UT, Latinwo LM, Ikediobi CO, Badisa RB and Darling-Reed SF: Protective effects of $\mathrm{N}$-acetylcysteine against cadmium-induced damage in cultured rat normal liver cells. Int J Mol Med 27: 243-248, 2011.

28. Odewumi CO, Buggs R, Badisa VL, Latinwo LM, Badisa RB, Ikediobi CO, Darling-Reed SF and Owens MA: Mitigative action of monoisoamyl-2,3-dimercaptosuccinate (MiADMS) against cadmium-induced damage in cultured rat normal liver cells. Toxicol In Vitro 25: 1733-1739, 2011.

29. Jonah MM and Bhattacharyya MH: Early changes in the tissue distribution of cadmium after oral but not intravenous cadmium exposure. Toxicology 58: 325-338, 1989. 
30. Solaiman D, Jonah MM, Miyazaki W, Ho G and Bhattacharyya MH: Increased metallothionein in mouse liver, kidneys, and duodenum during lactation. Toxicol Sci 60: 184-192, 2001.

31. Flora SJ, Mittal M and Mehta A: Heavy metal induced oxidative stress and its possible reversal by chelation therapy. Indian J Med Res 128: 501-523, 2008.

32. Duracková Z: Some current insights into oxidative stress. Physiol Res 59: 459-469, 2010.

33. Tanikawa K and Torimura T: Studies on oxidative stress in liver diseases: Important future trends in liver research. Med Mol Morphol 39: 22-27, 2006

34. Vera-Ramirez L, Pérez-Lopez P, Varela-Lopez A Ramirez-Tortosa M, Battino M and Quiles JL: Curcumin and liver disease. Biofactors 39: 88-100, 2013.

35. Zafeer MF, Waseem M, Chaudhary S and Parvez $S$ Cadmium-induced hepatotoxicity and its abrogation by thymoquinone. J Biochem Mol Toxicol 26: 199-205, 2012.

36. Amamou F, Nemmiche S, Meziane RK, Didi A, Yazit SM and Chabane-Sari D: Protective effect of olive oil and colocynth oil against cadmium-induced oxidative stress in the liver of Wistar rats. Food Chem Toxicol 78: 177-184, 2015.

37. Jain SC and Madhu A: Regulation of trigonellin in Trigonella species by chemical mutagenic treatments. Indian Drugs 26: 14-16, 1988.

38. Kamal R and Yadav R: Flavonoids from Trigonella polycerta in-vivo and in-vitro. J Phytological Res 4: 161-165, 1991.

39. Swain AR, Dutton SP and Truswell AS: Salicylates in foods. J Am Diet Assoc 85: 950-960, 1985.

40. Liu Y, Kakani R and Nair MG: Compounds in functional food fenugreek spice exhibit anti-inflammatory and antioxidant activities. Food Chemistry 131: 1187-1192, 2012.

41. Ahmadiani A, Javan M,Semnanian S, BaratE and Kamalinejad M: Anti-inflammatory and antipyretic effects of Trigonella foenum-graecum leaves extract in the rat. J Ethnopharmacol 75 283-286, 2001

42. McNamara MJ, Kasiewicz MJ, Linch SN, Dubay C and Redmond WL: Common gamma chain $(\gamma \mathrm{c})$ cytokines differentially potentiate TNFR family signaling in antigen-activated CD8(+) T cells. J Immunother Cancer 2: 28, 2014
43. Grönroos E, Terentiev AA, Punga T and Ericsson J: YY1 inhibits the activation of the $\mathrm{p} 53$ tumor suppressor in response to genotoxic stress. Proc Natl Acad Sci USA 101: 12165-12170, 2004.

44. Glahn F, Schmidt-Heck W,Zellmer S, Guthke R, Wiese J, Golka K, Hergenröder R, Degen GH, Lehmann T, Hermes M, et al: Cadmium, cobalt and lead cause stress response, cell cycle deregulation and increased steroid as well as xenobiotic metabolism in primary normal human bronchial epithelial cells which is coordinated by at least nine transcription factors. Arch Toxicol 82: 513-524, 2008.

45. Chen W, Zhang Z, Dong H and Jiang X: Molecular cloning and sequence analysis of selenoprotein $\mathrm{W}$ gene and its mRNA expression patterns in response to metabolic status and cadmium exposure in goldfish, Carassius auratus. Comp Biochem Physiol B Biochem Mol Biol 184: 1-9, 2015.

46. Huang C, Zhang Q, Li J, Shi X, Castranova V, Ju G, Costa M and Dong Z: Involvement of Erks activation in cadmium-induced AP-1 transactivation in vitro and in vivo. Mol Cell Biochem 222: $141-147,2001$

47. Mita P, Savas JN, Ha S, Djouder N, Yates JR III and Logan SK: Analysis of UR1 nuclear interaction with RPB5 and components of the R2TP/prefoldin-like complex. PLoS One 8: e63879, 2013.

48. Yang Z, Yang S, Qian SY, Hong JS, Kadiiska MB, Tennant RW, Waalkes MP and Liu J: Cadmium-induced toxicity in rat primary mid-brain neuroglia cultures: Role of oxidative stress from microglia. Toxicol Sci 98: 488-494, 2007.

49. Asagba SO: Alteration in the activity of oxidative enzymes in the tissues of male Wistar albino rats exposed to cadmium. Int J Occup Med Environ Health 23: 55-62, 2010.

50. Fabbri M, Urani C, Sacco MG, Procaccianti C and Gribaldo L: Whole genome analysis and microRNAs regulation in HepG2 cells exposed to cadmium. ALTEX 29: 173-182, 2012.

51. Ola-Mudathir FK and Suru SM: Onion and garlic extracts as potential antidotes for cadmium-induced biochemical alterations in prostate glands of rats. Andrologia 47: 1075-1082, 2014.

This work is licensed under a Creative Commons Attribution-NonCommercial-NoDerivatives 4.0 International (CC BY-NC-ND 4.0) License. 